\title{
Guideline recommendations for antimicrobial stewardship education for clinical nursing practice in hospitals: A scoping review
}

\author{
J Rout, MN; S Essack, PhD; P Brysiewicz, PhD \\ College of Health Sciences, University of KwaZulu-Natal, Durban, South Africa
}

Corresponding author: J Rout (joanrout@worldonline.co.za)

\begin{abstract}
Background. Antimicrobial stewardship (AMS) is a proactive healthcare intervention to improve patient outcomes by optimising antimicrobial use. Although nursing involvement is a recognised necessity, bedside nurses may not yet possess competencies to fulfil this role.

Objectives. To identify recommendations for AMS education for the bedside nurse in key global AMS guidelines.

Methods. Scoping review methodology was used to systematically search published and 'grey' literature in PubMed, EBSCOhost, Google Scholar, government websites and websites of professional societies and organisations. Search dates were from 1990 to 2020. Inclusion criteria were English language AMS guidelines for hospitals.

Results. Literature searches retrieved 1824 articles, with 43 meeting the review inclusion criteria. Reference was made to AMS nursing education in $23(53.4 \%)$ of the articles. Educational opportunities for nurses were recommended: inclusion of AMS concepts/content into undergraduate and postgraduate nursing curricula $(n=12 ; 27.9 \%)$, in-hospital training $(n=14 ; 32.5 \%)$ and continuing professional development $(n=6 ; 13.9 \%)$. Recommendations for nursing education were as follows: role of AMS in preventing antimicrobial resistance $(n=7 ; 16.2 \%)$, infection prevention and control $(n=3 ; 6.9 \%)$, diagnostics in AMS $(n=5 ; 11.6 \%)$, pharmacology $(n=11 ; 25.5 \%)$ and collaboration $(n=2 ; 4.6 \%)$. Identified nursing educational gaps were: nurses not recognising their role within AMS $(n=5 ; 11.6 \%)$, inadequate nursing resources and expertise for dosing, pharmacokinetic/pharmacodynamic strategies and managing possible drug incompatibilities with extended/prolonged infusions $(n=3 ; 6.9 \%)$, and inappropriate nurse disposal of antibiotic waste $(n=1 ; 2.3 \%)$.

Conclusions. Although recommendations for nursing education were found in many key AMS guidelines, few guidelines provided detailed descriptions of the nursing competencies that were required for this role.

Keywords. antimicrobial stewardship; education; guidelines; bedside nurse; scoping review.
\end{abstract}

South Afr J Crit Care 2021;37(3):104-114. https://doi.org/10.7196/SAJCC.2021.v37i3.482

Contributions of the study. This study serves to compile and highlight previously little-known recommendations within key international antimicrobial stewardship (AMS) guidelines for the education of clinical nurses in their AMS role. It provides a summary of expected clinical nurse competencies. It adds to current discussion within the literature on how to improve and support this critical nursing role.

The use of antibiotics has allowed enormous advances in human healthcare; however, antimicrobial resistance (AMR) threatens to counteract these lifesaving medications. Strategic objectives to address AMR in the World Health Organization (WHO) 'Global action plan on antimicrobial resistance' aim to: improve awareness and understanding of AMR through effective communication, education and training; improve knowledge about the extent of the problem through surveillance and research; reduce the incidence of infection; improve the use of antimicrobials; and implement sustainable programmes to reduce AMR. ${ }^{[1]}$ Changing the manner in which antibiotics are used is acknowledged as the most important way to reduce AMR; $;^{[2]}$ the primary goals of antimicrobial stewardship (AMS) are therefore to prevent or slow the emergence of AMR; optimise the selection, dose and duration of therapy; reduce adverse drug events, including secondary infection (e.g. Clostridium difficile antibiotic-associated diarrhoea); reduce morbidity and mortality; reduce length of stay; and reduce healthcare expenditures. ${ }^{[3]}$

To provide optimal evidence-based care of the patient, the nurse needs to understand that the nursing role within AMS is aimed at the prevention of AMR. Ongoing education forms the foundation of AMS programmes, ${ }^{[2,4,5]}$ and is a 'key factor in empowering nurses to take responsibility for AMS. ${ }^{[6]}$ Unfortunately, nurses' knowledge of AMS and antibiotics continues to be suboptimal, despite it being identified as an important aspect of the AMS role for nurses, ${ }^{[7-15]}$ affecting both nursing practice and communication with others within the multidisciplinary AMS team, ${ }^{[4,10,15-22]}$ possibly due to a historical focus on nursing documentation rather than interpretation. ${ }^{[10]}$

The importance of preparing nurses to support AMS strategies was acknowledged by the Royal College of Nursing (RCN) (UK) (2014) in a position paper, 'Antimicrobial resistance. RCN position on the nursing contribution: Antimicrobial resistance is an increasing global priority and one where nursing has a key contribution to make. ${ }^{[23]}$ A systematic scoping review was chosen as the appropriate methodology to map the literature ${ }^{[24]}$ for other key AMS guidelines offering educational recommendations for AMS clinical nursing practice in the hospital setting. A preliminary search of PROSPERO, MEDLINE, the Cochrane Database of Systematic Reviews and the Joanna Briggs Institute (JBI) 
Database of Systematic Reviews and Implementation Reports was conducted and no current or ongoing scoping reviews or systematic reviews on the topic were identified. This review title is registered with JBI Systematic Review and Open Science Framework (OSF).

\section{Methods Study design}

The scoping review was conducted in accordance with the JBI (2015) methodology for scoping reviews, ${ }^{[24]}$ based on the Arksey and O'Malley framework, ${ }^{[25]}$ with improvements by Levac et al. ${ }^{\left[{ }^{[26]}\right.} \mathrm{A}$ five-stage protocol for the scoping review was compiled by three reviewers, guided by the PRISMA Extension for Scoping Reviews (PRISMA-ScR): ${ }^{[27]}$ (i) identifying the research question; (ii) identifying relevant studies; (iii) study selection; (iv) charting the data; and ( $v$ ) collating, summarising and reporting results. ${ }^{[24-26]}$

\section{Identifying the research question}

Following an initial research question aiming to map AMS guideline recommendations for bedside nursing practice in acute-care hospitals, described in 'Guidelines for the hospital role of the clinical nurse in antimicrobial stewardship: A scoping review, ${ }^{[28]}$ a second research question was defined as: 'Do key antimicrobial stewardship guidelines and policies include recommendations for AMS education for bedside nursing practice, and what are these recommendations?' Objectives of the review were to describe: (i) nursing AMS gaps identified by AMS guideline documents; (ii) recommendations for AMS education for the bedside nurse; and (iii) recommendations for AMS educational opportunities for the bedside nurse.

\section{Identifying relevant studies \\ Inclusion and exclusion criteria}

English language documents published from 1990 to 2020 were considered and included publications prior to the first known AMS guideline (1997) ${ }^{[29]}$ (Table 1). The search strategy aimed to locate both published and unpublished ('grey' literature) ${ }^{[24-26]}$ guidelines specific to AMS (including recommendations, policy statements, position statements, white papers, standards, strategies, protocols, action plans or briefs) authored by government bodies, national healthcare organisations, interested healthcare societies, and medical, pharmacy and nursing professional bodies.

\section{Search strategy}

Database and manual searches were conducted in 2018 and updated in 2020 using a three-step search strategy: ${ }^{[2,30]}$ (i) a limited PubMed

\begin{tabular}{l} 
Table 1. Eligibility criteria \\
\hline Inclusion criteria \\
\hline - Guidelines published by ministries of health, medical \\
or nursing professional associations or healthcare professional \\
societies \\
- Guidelines related to antimicrobial stewardship and/or \\
antimicrobial resistance hospital programmes for the adult \\
patient \\
- Guidelines published in English \\
- Guidelines published from 1990 to 2020 \\
Exclusion criteria \\
- Hospital-specific guidelines \\
- Guidelines published in languages other than English \\
- Guidelines published before 1990
\end{tabular}

search was conducted to identify articles on the topic; (ii) text words contained in the titles and abstracts of relevant articles and index terms used to describe the articles were then used to develop a full search strategy. The search strategy, including all identified keywords and index terms, was adapted for each included information source and for electronic literature databases (PubMed and EBSCOhost (academic search complete), CINAHL, HealthSource, MEDLINE, Nursing/ Academic Edition) (Appendix 1: http://sajcc.org.za/public/sup/482. pdf); and (iii) manual searches were carried out on reference lists of identified key articles (Fig. 1). ${ }^{[31]}$

\section{Study selection}

After the search, all identified records were collated and uploaded to EndNote version X7.8 (EndNote, USA) and duplicates removed. The literature search yielded a total of 1824 articles, from which 1325 duplicate and non-relevant articles were removed. The two reviewers used a two-part selection process to exclude 357 articles on the basis of eligibility through first-level screening (using document titles and abstracts), and an additional 99 through second-level screening of the full text. In the case of documents retrieved from websites, which generally did not have abstracts, selection was based on title and full-text read. Any disagreements that arose between the reviewers were resolved through discussion or with a third reviewer. Fortythree documents were finally selected, using inclusion and exclusion criteria (Table 1), and the JBI Population Concept Context (PCC) framework: ${ }^{[30]}(\mathrm{P})$ opulation - nurses who practise in a hospital setting; (C)oncept - guideline recommendations for clinical nurse education; and (C)ontext - AMS strategies and interventions that have developed to address AMR. The selection process was documented according to PRISMA-ScR (Fig. 1). ${ }^{[27]}$

\section{Charting the data}

Data were extracted from documents included in the scoping review by two independent reviewers using a data-extraction tool that they developed. Peters et al. ${ }^{[30]}$ suggest that a scoping review should map the literature with regard to time, location, source and origin. The

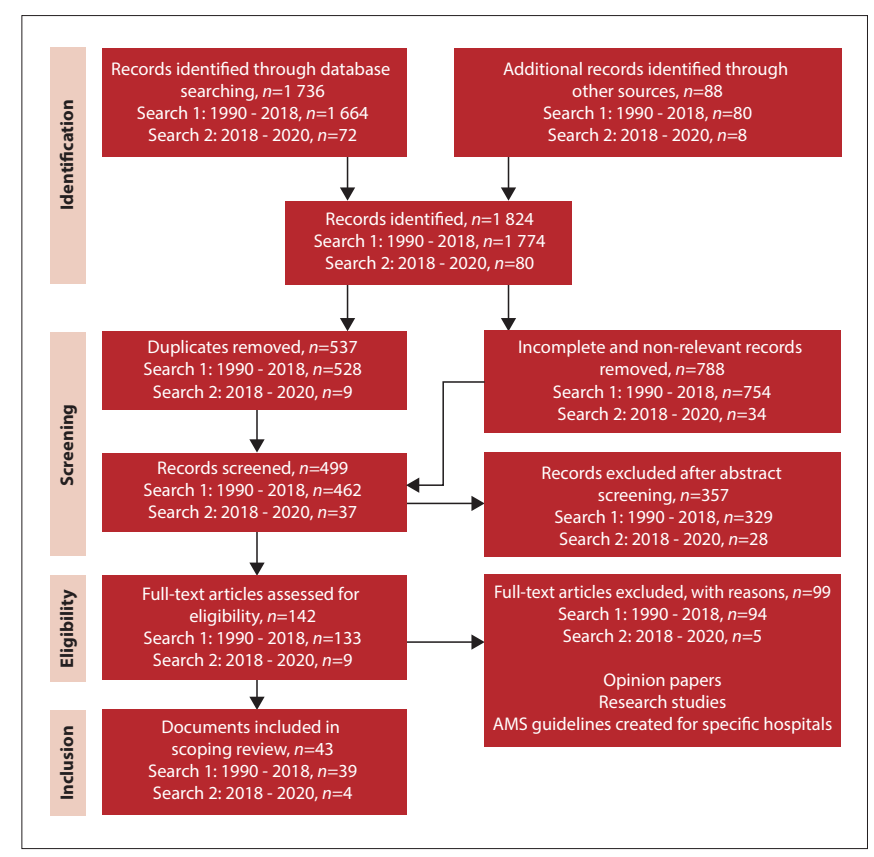

Fig. 1. PRISMA flow diagram showing selection process. $(A M S=$ antimicrobial stewardship. $)^{[27]}$ 
data from the 43 studies that were included were therefore charted according to the authors, organisations/societies that they were representing, year published, country of origin, overall goal and objectives of the guideline document (Table 2). ${ }^{[30]}$

\section{Collating, summarising and reporting results}

Following scoping review methodology, we applied a common 'descriptive-analytical' framework to the reviews. ${ }^{[2,25]}$ A narrative synthesis ${ }^{[24]}$ was used to answer the objectives of the study, as described below.

\section{Ethical approval}

Ethical approval (ref. no. BE709/18) was obtained from the Biomedical Research Ethics Committee of the University of KwaZuluforms part of a larger study into clinical nurse

\section{Results}

\section{Origin and purpose of AMS guideline documents}

Of the 43 guideline documents identified by the scoping review, ${ }^{[1,2,23,29,32-70]}$ the majority were from government ministries/departments of health $(n=23 ; 53.4 \%)$, professional organisations $(n=6 ; 13.9 \%)$, professional societies $(n=10$; $23.2 \%)$, world organisations $(n=2 ; 4.6 \%)$ and committees and commissions $(n=2 ; 4.6 \%)$, and were published in professional journals or placed on websites. Five (11.6\%) of the selected documents were from professional nursing organisations. Recommendations for AMS education were made by $23(53.4 \%)$ of the guideline documents reviewed: USA $(n=8$; $18.6 \%), \mathrm{EU}(n=4 ; 9.3 \%)$, Africa $(n=4 ; 9.3 \%)$, Australia $(n=3 ; 6.9 \%)$, Canada $(n=2 ; 4.6 \%)$, Asia $(n=1 ; 2.3 \%)$ and international $(n=1 ; 2.3 \%)$ (Fig. 2). Natal, Durban, South Africa. This review practice within AMS.

\section{Educational gaps identified with the AMS role of the bedside nurse}

Eight documents (18.6\%) referred to specific nursing attitudes and practices, which were viewed as educational gaps. These were: nurses may not recognise/understand the AMS nursing role and that much of their daily clinical practice supports AMS strategies $(n=5$; $11.6 \%$ ) inadequate expertise with multiple or complex infusions, such as extended/ prolonged infusions $(n=3 ; 6.9 \%)$ to prevent possible drug incompatibilities $(n=1 ; 2.3 \%)$ and to support dose optimisation $(n=2$; $4.6 \%$ ); and incorrect disposal of waste items containing residue of antimicrobial medicines, e.g. residue in vials and intravenous (IV) infusion administration lines, as these may have environmental implications for AMR $(n=1 ; 2.3 \%)$ (Table 2).

\section{Recommendations for AMS education for the bedside nurse}

Twenty-three documents (53.4\%) made recommendations for AMS education, described in 13 documents (30.2\%) as: the role of AMS in preventing AMR ( $n=7$; $16.2 \%)$, infection prevention and control (IPC in AMS) $(n=3 ; 6.9 \%)$, diagnostics in AMS $(n=5 ; 11.6 \%)$, pharmacology in AMS $(n=11 ; 25.5 \%)$ and collaboration in AMS $(n=2$; 4.6\%) (Table 3)

\section{Recommendations for AMS educational opportunities for the bedside nurse}

Twenty-one documents (48.8\%) made suggestions for educational opportunities to be created for nurses. There were 12 suggestions (27.9\%) for the inclusion of AMS concepts/content into curricula: undergraduate education $(n=8 ; 18.6 \%)$ and

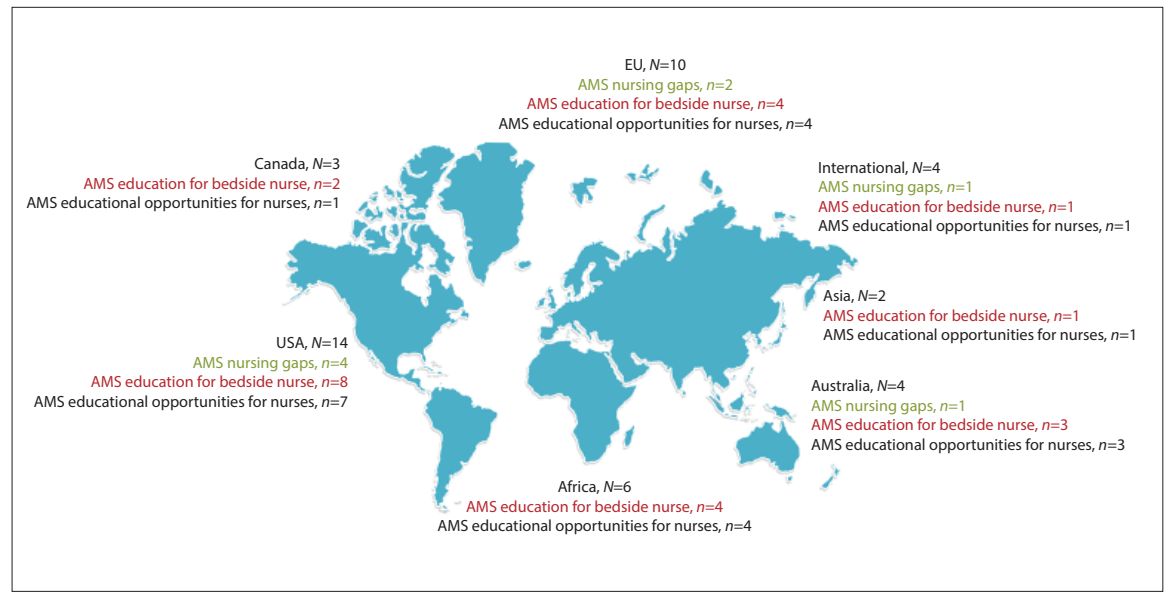

Fig. 2. Geographical distribution of guidelines $(\mathrm{N}=43)$. (AMS = antimicrobial stewardship. $)$ postgraduate education $(n=4 ; 9.3 \%)$. Fourteen documents $(32.5 \%)$ suggested that hospitals should provide nurses with AMS training: on induction $(n=2 ; 4.6 \%)$, in-service education from the AMS team $(n=4 ; 9.3 \%)$, in-service education on AMS rounds $(n=2 ; 4.6 \%)$, in-service AMS education from IPC specialist nurses ( $n=2 ; 4.6 \%)$, audit feedback from AMS teams $(n=6 ; 13.9 \%)$; and six documents suggested that nurses should access AMS information through continuing professional development (CPD) opportunities ( $n=6$; $13.9 \%)$, although it was not clear from the documents whether this should be provided by hospitals or other forums (Table 2).

\section{Discussion}

The need to build expertise in preventing AMR is clear and can only be achieved by a new emphasis on equipping nurses with the knowledge, skills and competencies required to support multidisciplinary engagement of AMS. ${ }^{[18,71]}$ In a worldwide survey of AMS educational opportunities provided to healthcare students (WHO) ${ }^{[72]}$ nurses were among the fewest of healthcare groups to be targeted in educational interventions. Our scoping review identified many documents that emphasised the importance of ensuring that nurses who work closely with patients received education and training to equip them to function effectively in the AMS nursing role. However, only 13 documents described specific AMS educational content to develop nursing expertise - two of these were nursing organisations (the RCN and the American Nurses Association (ANA)) ${ }^{[23,56]}$ (Table 2).

\section{Participation in AMS strategies}

Training and education of nurses to increase awareness of antimicrobial use facilitate optimal antimicrobial treatment, monitoring and administration, ${ }^{[16,73-76]}$ and necessitate concerted educational interventions to build expertise. ${ }^{[18,75]}$ Recommendations for education were categorised into five broad categories (Table 3). It is important that these needs are included in nurse educational programmes. In 2014, a Scottish survey of nurse knowledge of AMS found that only $22 \%$ of nurses understood the term 'antimicrobial stewardship. ${ }^{[7]}$ Subsequent studies showed some improvement, with $54 \%$ of nurses in the UK (2017), ${ }^{[14]} 65 \%$ of Australian nurses (2017) ${ }^{[8]}$ and, more recently, 64\% (2018), ${ }^{[77]} 38 \%(2018)^{[11]}$ and $48 \%(2019),{ }^{[12]}$ respectively, of nurses in the USA recognising this term. In these studies, 


\begin{tabular}{|c|c|c|c|}
\hline $\begin{array}{l}\text { Year } \\
\text { published }\end{array}$ & Authors & $\begin{array}{l}\text { Country/ } \\
\text { region of } \\
\text { origin }\end{array}$ & Organisation/society \\
\hline 1997 & Shlaes et al. ${ }^{[29]}$ & USA & $\begin{array}{l}\text { Society for Healthcare } \\
\text { Epidemiology of America } \\
\text { and Infectious Diseases } \\
\text { Society of America }\end{array}$ \\
\hline 2006 & Nathwani ${ }^{[32]}$ & Scotland & $\begin{array}{l}\text { Scottish Medicines } \\
\text { Consortium }\end{array}$ \\
\hline
\end{tabular}

200

Pediatric Infectious
2007

Strategy for the Control of

Antimicrobial

Resistance in

Ireland $^{[34]}$

Drew et al. ${ }^{[35]}$

Strategy for the Control of Antimicrobial

Resistance in

Ireland $^{[36]}$

Duguid and Cruikshank $^{[37]}$

ociety for

Healthcare

Epidemiology of America, Infectious

Diseases Society

of America, and

Diseases Society ${ }^{[39]}$

USA

Ireland

USA

Society of Infectious

Diseases Pharmacists

Ireland

Health Protection

Surveillance Centre,

Ireland

Australia

Australian Commission on Safety and Quality in Health Care, Australian

Government

Infectious Diseases Society of America

Society for Healthcare Epidemiology of America,

Infectious Diseases

Society of America,

and Pediatric Infectious

Diseases Society

Singapore Ministry of Health

UK

England $^{[41]}$

2014
Centers for Disease USA

Control and

Prevention ${ }^{[2]}$

\section{Objectives}

1: Identification of nursing AMS gaps $(n=8)$

2: Recommendations for AMS education for the bedside nurse $(n=23)$

Overall goal of $\quad 3$ : Recommendations for AMS educational guideline

Guidelines for the 1: no

prevention of AMR 2: nurse education (no specific recommendations)

in hospitals 3: nurse education opportunities - audit feedback from AMS team

Recommendations $\quad 1:$ no

for antimicrobial use 2: nurse education - pharmacology in AMS

in $\mathrm{AMS}$

3: nurse education opportunities - CPD

Guidelines for $\quad$ 1: no

developing AMS 2: no

programmes in $\quad 3:$ no

hospitals

Annual report on 1: no

AMR 2: no

3: no

Guidelines for AMS 1: nursing gap - inadequate nursing expertise with extended/prolonged infusions/drug incompatibilities

2: no

3: no

Guidelines for AMS 1: no

in hospitals

2: nurse education (no specific recommendations)

3: nurse education opportunities - induction training

AMS in hospitals $1:$ no

2: nurse education - role of AMS in preventing AMR; pharmacology in AMS

3: nurse education opportunities - in-service training (from IPC specialist nurses)

Policy 1: no

recommendations $\quad 2$ : no

for AMR 3: no

Policy statement on 1 : no

AMS 2: no

3: no

Guidelines for AMS 1: no training and practice 2 : no

3: no

Department of Health and Guidelines on 1: no Social Care antimicrobial 2: no prescribing and 3: no stewardship competencies

US Department of Health Core elements 1: no and Human Services

2: nurse education - role of AMS in preventing AMR; pharmacology in AMS

3: nurse education opportunities - audit feedback from AMS team 


\begin{tabular}{|c|c|c|c|c|c|}
\hline $\begin{array}{l}\text { Year } \\
\text { published }\end{array}$ & Authors & $\begin{array}{l}\text { Country/ } \\
\text { region of } \\
\text { origin }\end{array}$ & Organisation/society & $\begin{array}{l}\text { Overall goal of } \\
\text { guideline }\end{array}$ & $\begin{array}{l}\text { Objectives } \\
\text { 1: Identification of nursing AMS gaps }(n=8) \\
\text { 2: Recommendations for AMS education for the } \\
\text { bedside nurse ( } n=23) \\
\text { 3: Recommendations for AMS educational } \\
\text { opportunities for the bedside nurse }(n=21)\end{array}$ \\
\hline 2014 & $\begin{array}{l}\text { National } \\
\text { Department of } \\
\text { Health }^{[42]}\end{array}$ & South Africa & $\begin{array}{l}\text { National Department of } \\
\text { Health }\end{array}$ & $\begin{array}{l}\text { Antimicrobial } \\
\text { Resistance National } \\
\text { Strategy Framework } \\
2014-2024\end{array}$ & $\begin{array}{l}\text { 1: no } \\
\text { 2: nurse education (no specific recommendations) } \\
\text { 3: nurse education opportunities - undergraduate } \\
\quad \text { and postgraduate education }\end{array}$ \\
\hline 2014 & $\begin{array}{l}\text { Ministry of } \\
\text { Health }^{[43]}\end{array}$ & Malaysia & Ministry of Health & $\begin{array}{l}\text { Protocol for } \\
\text { implementation of } \\
\text { AMS programmes in } \\
\text { healthcare facilities }\end{array}$ & $\begin{array}{l}\text { 1: no } \\
\text { 2: nurse education (no specific recommendations) } \\
\text { 3: nurse education opportunities - induction } \\
\text { training; in-service training (from AMS team); } \\
\text { CPD }\end{array}$ \\
\hline 2014 & $\begin{array}{l}\text { Royal College of } \\
\text { Nursing }^{[23]}\end{array}$ & UK & Royal College of Nursing & $\begin{array}{l}\text { Royal College of } \\
\text { Nursing position on } \\
\text { the nursing role in } \\
\text { combating AMR }\end{array}$ & $\begin{array}{l}\text { 1: nursing gap - unrecognised AMS role of the } \\
\text { nurse } \\
\text { 2: nurse education - role of AMS in preventing } \\
\text { AMR; pharmacology in AMS } \\
\text { 3: nurse education opportunities - undergraduate } \\
\text { and postgraduate education }\end{array}$ \\
\hline 2015 & $\begin{array}{l}\text { National } \\
\text { Department of } \\
\text { Health }^{[44]}\end{array}$ & South Africa & $\begin{array}{l}\text { National Department of } \\
\text { Health }\end{array}$ & $\begin{array}{l}\text { Implementation plan } \\
\text { for the Antimicrobial } \\
\text { Resistance Strategy } \\
\text { Framework in South } \\
\text { Africa: } 2014 \text { - } 2019\end{array}$ & $\begin{array}{l}\text { 1: no } \\
\text { 2: nurse education (no specific recommendations) } \\
\text { 3: nurse education opportunities - undergraduate } \\
\text { and postgraduate education; in-service training } \\
\text { (from AMS team); in-service training (from IPC } \\
\text { specialist nurses); CPD }\end{array}$ \\
\hline 2015 & $\begin{array}{l}\text { Department of } \\
\text { Health }^{[45]}\end{array}$ & $\begin{array}{l}\text { Western } \\
\text { Australia }\end{array}$ & Ministry of Health & AMS policy & $\begin{array}{l}\text { 1: no } \\
\text { 2: nurse education (no specific recommendations) } \\
\text { 3: nurse education opportunities - audit feedback } \\
\text { from AMS team }\end{array}$ \\
\hline 2015 & $\mathrm{WHO}^{[1]}$ & International & WHO & $\begin{array}{l}\text { Global Action Plan } \\
\text { on AMR }\end{array}$ & $\begin{array}{l}\text { 1: no } \\
\text { 2: no } \\
\text { 3: no }\end{array}$ \\
\hline 2016 & $\begin{array}{l}\text { Communicable } \\
\text { and Infectious } \\
\text { Disease Steering } \\
\text { Committee }^{[46]}\end{array}$ & Canada & $\begin{array}{l}\text { Pan-Canadian Public } \\
\text { Health Network }\end{array}$ & $\begin{array}{l}\text { Recommendations } \\
\text { for AMS }\end{array}$ & $\begin{array}{l}\text { 1: no } \\
\text { 2: no } \\
\text { 3: no }\end{array}$ \\
\hline 2016 & Barlam et al. ${ }^{[47]}$ & USA & $\begin{array}{l}\text { Infectious Diseases } \\
\text { Society of America and } \\
\text { Society for Healthcare } \\
\text { Epidemiology of America }\end{array}$ & $\begin{array}{l}\text { Guidelines on } \\
\text { implementing an } \\
\text { AMS programme }\end{array}$ & $\begin{array}{l}\text { 1: nursing gap - inadequate nursing expertise in } \\
\text { supporting dosing PK/PD strategies } \\
\text { 2: nurse education (no specific recommendations) } \\
\text { 3: nurse education opportunities - undergraduate } \\
\text { education }\end{array}$ \\
\hline 2016 & $\begin{array}{l}\text { National } \\
\text { Department of } \\
\text { Health }^{[48]}\end{array}$ & South Africa & $\begin{array}{l}\text { National Department of } \\
\text { Health }\end{array}$ & $\begin{array}{l}\text { Background } \\
\text { document on AMR }\end{array}$ & $\begin{array}{l}\text { 1: no } \\
\text { 2: no } \\
\text { 3: no }\end{array}$ \\
\hline 2016 & $\begin{array}{l}\text { National } \\
\text { Department of } \\
\text { Health }^{[49]}\end{array}$ & South Africa & $\begin{array}{l}\text { National Department of } \\
\text { Health }\end{array}$ & Guidelines for AMS & $\begin{array}{l}\text { 1: no } \\
\text { 2: nurse education (no specific recommendations) } \\
\text { 3: nurse education opportunities - in-service } \\
\quad \text { training (on AMS ward rounds); CPD }\end{array}$ \\
\hline 2016 & De With et al. ${ }^{[50]}$ & Germany & $\begin{array}{l}\text { German Society for } \\
\text { Infectious Diseases }\end{array}$ & $\begin{array}{l}\text { Guideline for } \\
\text { implementation of } \\
\text { AMS }\end{array}$ & $\begin{array}{l}\text { 1: no } \\
\text { 2: no } \\
\text { 3: no }\end{array}$ \\
\hline 2016 & $\begin{array}{l}\text { HealthCare CAN } \\
\text { and National } \\
\text { Collaborating } \\
\text { Centre for } \\
\text { Infectious } \\
\text { Diseases }^{[51]}\end{array}$ & Canada & $\begin{array}{l}\text { Public Health Agency of } \\
\text { Canada }\end{array}$ & $\begin{array}{l}\text { National action plan } \\
\text { on AMS }\end{array}$ & $\begin{array}{l}\text { 1: no } \\
\text { 2: nurse education (no specific recommendations) } \\
\text { 3: no }\end{array}$ \\
\hline
\end{tabular}


Table 2. (continued) Guidelines included in the study $(N=43)$

\begin{tabular}{|c|c|c|c|c|c|}
\hline $\begin{array}{l}\text { Year } \\
\text { published }\end{array}$ & Authors & $\begin{array}{l}\text { Country/ } \\
\text { region of } \\
\text { origin }\end{array}$ & Organisation/society & $\begin{array}{l}\text { Overall goal of } \\
\text { guideline }\end{array}$ & $\begin{array}{l}\text { bedside nurse }(n=23) \\
\text { 3: Recommendations for AMS educational } \\
\text { opportunities for the bedside nurse }(n=21)\end{array}$ \\
\hline 2016 & $\begin{array}{l}\text { Healthcare } \\
\text { Infection Control } \\
\text { Practices Advisory } \\
\text { Committee }^{[52]}\end{array}$ & USA & $\begin{array}{l}\text { US Federal Advisory } \\
\text { Committee }\end{array}$ & Guidelines for AMS & $\begin{array}{l}\text { 1: no } \\
\text { 2: no } \\
\text { 3: no }\end{array}$ \\
\hline 2016 & Levy Hara et al..$^{[53]}$ & International & $\begin{array}{l}\text { Antimicrobial } \\
\text { Stewardship and } \\
\text { Resistance Working } \\
\text { Groups of the } \\
\text { International Society of } \\
\text { Chemotherapy }\end{array}$ & $\begin{array}{l}\text { Recommendations } \\
\text { for antibiotic use in } \\
\text { AMS }\end{array}$ & $\begin{array}{l}\text { 1: no } \\
\text { 2: no } \\
\text { 3: no }\end{array}$ \\
\hline 2016 & Morgan et al..$^{[54]}$ & USA & $\begin{array}{l}\text { Society for Healthcare } \\
\text { Epidemiology of America }\end{array}$ & $\begin{array}{l}\text { Recommendations } \\
\text { for AMS }\end{array}$ & $\begin{array}{l}\text { 1: no } \\
\text { 2: no } \\
\text { 3: no }\end{array}$ \\
\hline 2016 & $\begin{array}{l}\text { National Institute } \\
\text { for Health and Care } \\
\text { Excellence }^{[55]}\end{array}$ & UK & Department of Health & $\begin{array}{l}\text { Recommendations } \\
\text { for antibiotic use in } \\
\text { AMS }\end{array}$ & $\begin{array}{l}\text { 1: no } \\
\text { 2: no } \\
\text { 3: no }\end{array}$ \\
\hline 2017 & $\begin{array}{l}\text { American Nurses } \\
\text { Association/Centers } \\
\text { for Disease Control } \\
\text { and Prevention } \\
\text { Workgroup }^{[56]}\end{array}$ & USA & $\begin{array}{l}\text { American Nurses } \\
\text { Association/Centers for } \\
\text { Disease Control and } \\
\text { Prevention Workgroup }\end{array}$ & $\begin{array}{l}\text { White paper } \\
\text { recommendations } \\
\text { on the role of } \\
\text { registered nurses in } \\
\text { hospital AMS }\end{array}$ & $\begin{array}{l}\text { 1: nursing gap - unrecognised AMS role of the } \\
\text { nurse } \\
\text { 2: nurse education - IPC in AMS; diagnostic AMS; } \\
\text { pharmacology in AMS; collaboration in AMS } \\
\text { 3: nurse education opportunities - undergraduate } \\
\text { education; in-service training (on AMS ward } \\
\text { rounds); in-service training (from AMS team) }\end{array}$ \\
\hline 2017 & $\begin{array}{l}\text { American Society } \\
\text { of Health-System } \\
\text { Pharmacists }^{[57]}\end{array}$ & USA & $\begin{array}{l}\text { American Society } \\
\text { of Health-System } \\
\text { Pharmacists }\end{array}$ & $\begin{array}{l}\text { Guidelines for the } \\
\text { implementation of } \\
\text { AMS programmes }\end{array}$ & $\begin{array}{l}\text { 1: nursing gap -inadequate nursing expertise in } \\
\text { supporting dosing PK/PD strategies } \\
\text { 2: nurse education - pharmacology in AMS } \\
\text { 3: no }\end{array}$ \\
\hline 2017 & $\begin{array}{l}\text { Canadian Nurses } \\
\text { Association }^{[58]}\end{array}$ & Canada & $\begin{array}{l}\text { Canadian Nurses } \\
\text { Association }\end{array}$ & $\begin{array}{l}\text { Brief on the use of } \\
\text { nurses in combating } \\
\text { AMR }\end{array}$ & $\begin{array}{l}\text { 1: no } \\
\text { 2: nurse education (no specific recommendations) } \\
\text { 3: nurse education opportunities - CPD }\end{array}$ \\
\hline 2017 & $\begin{array}{l}\text { Department of } \\
\text { Health }^{[59]}\end{array}$ & Australia & Ministry of Health & $\begin{array}{l}\text { National AMR } \\
\text { strategy } 2015 \text { - } 2019 \\
\text { progress report }\end{array}$ & $\begin{array}{l}\text { 1: no } \\
\text { 2: no } \\
\text { 3: no }\end{array}$ \\
\hline 2017 & $\begin{array}{l}\text { European } \\
\text { Commission }^{[60]}\end{array}$ & $\mathrm{EU}$ & European Commission & $\begin{array}{l}\text { Guidelines for } \\
\text { antimicrobial use in } \\
\text { human health }\end{array}$ & $\begin{array}{l}\text { 1: no } \\
\text { 2: nurse education - pharmacology in AMS } \\
\text { 3: nurse education opportunities - undergraduate } \\
\text { and postgraduate education; CPD }\end{array}$ \\
\hline 2017 & $\begin{array}{l}\text { European } \\
\text { Federation } \\
\text { of Nurses } \\
\text { Associations }{ }^{[61]}\end{array}$ & EU & $\begin{array}{l}\text { European Federation of } \\
\text { Nurses Associations }\end{array}$ & $\begin{array}{l}\text { Recommendations } \\
\text { for nurses' role in } \\
\text { combating AMR }\end{array}$ & $\begin{array}{l}\text { 1: nursing gap - unrecognised AMS role of the } \\
\text { nurse } \\
\text { 2: no } \\
\text { 3: no }\end{array}$ \\
\hline 2017 & $\begin{array}{l}\text { International } \\
\text { Council of } \\
\text { Nurses }^{[62]}\end{array}$ & International & $\begin{array}{l}\text { International Council of } \\
\text { Nurses }\end{array}$ & $\begin{array}{l}\text { Position statement } \\
\text { on nurses' role in } \\
\text { combating AMR }\end{array}$ & $\begin{array}{l}\text { 1: nursing gap -unrecognised AMS role of the } \\
\text { nurse } \\
\text { 2: no } \\
\text { 3: no }\end{array}$ \\
\hline 2017 & $\begin{array}{l}\text { Ministerial } \\
\text { Advisory } \\
\text { Committee on } \\
\text { Antimicrobial } \\
\text { Resistance }^{[63]}\end{array}$ & South Africa & $\begin{array}{l}\text { National Department of } \\
\text { Health }\end{array}$ & $\begin{array}{l}\text { Guidelines on } \\
\text { implementation of } \\
\text { AMS using a One } \\
\text { Health approach }\end{array}$ & $\begin{array}{l}\text { 1: no } \\
\text { 2: no } \\
\text { 3: no }\end{array}$ \\
\hline 2017 & $\begin{array}{l}\text { The Joint } \\
\text { Commission }^{[64]}\end{array}$ & USA & $\begin{array}{l}\text { Standards-setting and } \\
\text { accrediting body for US } \\
\text { healthcare }\end{array}$ & Standard for AMS & $\begin{array}{l}\text { 1: no } \\
\text { 2: nurse education - role of AMS in preventing } \\
\text { AMR; pharmacology in AMS } \\
\text { 3: nurse education opportunities - in-service } \\
\text { training (from AMS team); audit feedback from } \\
\text { AMS team }\end{array}$ \\
\hline
\end{tabular}


Table 2. (continued) Guidelines included in the study $(N=43)$

\begin{tabular}{|c|c|c|c|c|c|}
\hline $\begin{array}{l}\text { Year } \\
\text { published }\end{array}$ & Authors & $\begin{array}{l}\text { Country/ } \\
\text { region of } \\
\text { origin }\end{array}$ & Organisation/society & $\begin{array}{l}\text { Overall goal of } \\
\text { guideline }\end{array}$ & $\begin{array}{l}\text { Objectives } \\
\text { 1: Identification of nursing AMS gaps ( } n=8) \\
\text { 2: Recommendations for AMS education for the } \\
\text { bedside nurse ( } n=23) \\
\text { 3: Recommendations for AMS educational } \\
\text { opportunities for the bedside nurse }(n=21)\end{array}$ \\
\hline 2018 & $\begin{array}{l}\text { Australian } \\
\text { Commission on } \\
\text { Safety and Quality } \\
\text { in Health Care }{ }^{[65]}\end{array}$ & Australia & Australian Government & $\begin{array}{l}\text { AMS in Australian } \\
\text { healthcare }\end{array}$ & $\begin{array}{l}\text { 1: nursing gap - unrecognised AMS role of the } \\
\text { nurse; nursing disposal of used antibiotic vials/ } \\
\text { infusion waste } \\
\text { 2: nurse education - role of AMS in preventing } \\
\text { AMR; IPC in AMS; diagnostic AMS; } \\
\text { pharmacology in AMS; collaboration in AMS } \\
\text { 3: nurse education opportunities - undergraduate } \\
\text { education }\end{array}$ \\
\hline 2018 & Hawkey et al. ${ }^{[66]}$ & UK & $\begin{array}{l}\text { Joint Working Party of the } \\
\text { British Society } \\
\text { for Antimicrobial } \\
\text { Chemotherapy, the } \\
\text { Healthcare Infection } \\
\text { Society and the British } \\
\text { Infection } \\
\text { Association }\end{array}$ & $\begin{array}{l}\text { Recommendations } \\
\text { for antibiotic use } \\
\text { within AMS }\end{array}$ & $\begin{array}{l}\text { 1: no } \\
\text { 2: no } \\
\text { 3: no }\end{array}$ \\
\hline 2018 & Manning et al..$^{[67]}$ & USA & $\begin{array}{l}\text { Association for } \\
\text { Professionals in } \\
\text { Infection Control and } \\
\text { Epidemiology and the } \\
\text { Society for Healthcare } \\
\text { Epidemiology of America }\end{array}$ & $\begin{array}{l}\text { Position paper on } \\
\text { the role of infection } \\
\text { prevention and } \\
\text { control within AMS }\end{array}$ & $\begin{array}{l}\text { 1: no } \\
\text { 2: nurse education - diagnostic AMS } \\
\text { 3: nurse education opportunities - audit feedback } \\
\text { from AMS team }\end{array}$ \\
\hline 2018 & $\mathrm{WHO}^{[68]}$ & International & WHO & $\begin{array}{l}\text { WHO competency } \\
\text { framework for health } \\
\text { workers' education } \\
\text { and training on } \\
\text { AMR }\end{array}$ & $\begin{array}{l}\text { 1: no } \\
\text { 2: nurse education - role of AMS in preventing } \\
\text { AMR; IPC in AMS; diagnostic AMS } \\
\text { 3: nurse education opportunities - undergraduate } \\
\text { education; in-service training }\end{array}$ \\
\hline 2019 & $\begin{array}{l}\text { Centers for Disease } \\
\text { Control and } \\
\text { Prevention }^{[69]}\end{array}$ & USA & $\begin{array}{l}\text { US Department of Health } \\
\text { and Human Services }\end{array}$ & $\begin{array}{l}\text { The core elements } \\
\text { of hospital AMS } \\
\text { programmes: } 2019\end{array}$ & $\begin{array}{l}\text { 1: no } \\
\text { 2: nurse education - diagnostic AMS; } \\
\text { pharmacology in AMS } \\
\text { 3: nurse education opportunities - audit feedback } \\
\text { from AMS team }\end{array}$ \\
\hline 2019 & $\begin{array}{l}\text { National } \\
\text { Department of } \\
\text { Health }^{[70]}\end{array}$ & South Africa & $\begin{array}{l}\text { National Department of } \\
\text { Health }\end{array}$ & $\begin{array}{l}\text { Guidelines for the } \\
\text { prevention and } \\
\text { containment of } \\
\text { AMR in South } \\
\text { African hospitals }\end{array}$ & $\begin{array}{l}\text { 1: no } \\
\text { 2: nurse education - role of AMS in preventing } \\
\quad \text { AMR; pharmacology in AMS } \\
\text { 3: nurse education opportunities - in-service } \\
\text { training }\end{array}$ \\
\hline
\end{tabular}

knowledge of antibiotics was reported as limited: $64 \%$ in Scotland, ${ }^{[7]}$ $57 \%$ in Australia, ${ }^{[8]} 63 \%$ in the USA ${ }^{[11]}$ and $68 \%$ in the UK. ${ }^{[14]}$ In the last study, nurses reported that they were unaware that omitted doses of antibiotics were undesirable (40\%), adding that although institution AMS guidelines were available, these were not referred to (54\%), citing workload and time constraints (79\%). ${ }^{[14]}$

Time constraints and prescriber 'pushback' (described as resistance to nursing contribution) were cited in several US studies in 2018: time constraints (85.5\%) and prescriber pushback (70.4\%) were both viewed by participants in a 'knowledge, attitudes and practice' study as barriers to effective nurse participation in AMS. ${ }^{[77]}$ This was less evident in a survey of acute-care nurses from five academic hospitals in New York, ${ }^{[11]}$ where nurses felt that discussions regarding the appropriateness of antimicrobial treatment in relation to culture results were generally difficult, but fewer nurses cited lack of time (35\%) and concern that their input would not be well received by prescribers $(28 \%)$. A complementary qualitative study conducted simultaneously in New York, ${ }^{[10]}$ with the aim of examining attitudes towards nurse-driven AMS activities recommended by the ANA/Centers for Disease Control and Prevention (CDC) white paper, ${ }^{[56]}$ found that nurses were uncomfortable taking responsibility for several AMS strategies, including differentiating between an adverse effect and true allergy to an antibiotic, and initiating an antibiotic 'timeout'. This situation was attributed to knowledge gaps, workflow considerations, prescriber pushback and perceptions of duplicative work.

\section{Integration of AMS learning into existing education curricula}

Reviewed documents suggest that AMS concepts should be integrated into the current requirement for nursing education within microbiology, pharmacology and applied clinical education, starting with preregistration training. Recommendations also included that consideration 
Table 3. Guideline recommendations for AMS education for the hospital-based nurse

\begin{tabular}{|c|c|c|}
\hline Education & Recommendation & Country \\
\hline \multirow[t]{4}{*}{ AMS } & Training on role and use of AMS guidelines and policies $(n=3 ; 6.9 \%)$ & Africa, ${ }^{[70]}$ Australia, ${ }^{[65]}$ international ${ }^{[68]}$ \\
\hline & Information on how to access resources $(n=1 ; 2.3 \%)$ & Australia $^{[65]}$ \\
\hline & Education on what AMR is and how it can be contained $(n=5 ; 11.6 \%)$ & Australia, ${ }^{[37,65]} \mathrm{EU}^{[23]} \mathrm{USA}^{[2,64]}$ \\
\hline & Education on the link of AMS with patient safety $(n=1 ; 2.3 \%)$ & Australia $^{[65]}$ \\
\hline \multirow[t]{2}{*}{ IPC in AMS } & Training on infection management and control $(n=2 ; 4.6 \%)$ & Australia, ${ }^{[65]}$ international ${ }^{[68]}$ \\
\hline & Education on the indications for MC\&S testing ( $n=1 ; 2.3 \%)$ & $\mathrm{USA}^{[56]}$ \\
\hline \multirow[t]{6}{*}{ Diagnostic AMS } & Education on the risks associated with inappropriate testing $(n=1 ; 2.3 \%)$ & $\mathrm{USA}^{[56]}$ \\
\hline & Training on optimal timing of collection of microbiological specimens $(n=1 ; 2.3 \%)$ & Australia ${ }^{[65]}$ \\
\hline & Education and training on the optimal quality of microbiological specimens $(n=4 ; 9.3 \%)$ & International, ${ }^{[68]} \mathrm{USA}^{[56,67,69]}$ \\
\hline & Training on interpretation of microbiology results $(n=3 ; 6.9 \%)$ & International, ${ }^{[68]} \mathrm{USA}^{[56,67]}$ \\
\hline & Education on the significance of differences between infection and colonisation $(n=2 ; 4.6 \%)$ & Australia, ${ }^{[65]} \mathrm{USA}^{[56]}$ \\
\hline & Training on interpretation of the antibiogram $(n=1 ; 2.3 \%)$ & $\mathrm{USA}^{[56]}$ \\
\hline \multirow{11}{*}{$\begin{array}{l}\text { Pharmacology } \\
\text { in AMS }\end{array}$} & Education on antimicrobial pharmacotherapy $(n=3 ; 6.9 \%)$ & Africa, ${ }^{[70]}$ Australia, ${ }^{[65]}$ USA $^{[69]}$ \\
\hline & Education on optimal prescribing $(n=6 ; 13.9 \%)$ & Australia, ${ }^{[37]} \mathrm{EU}^{[23,32,60]} \mathrm{USA}^{[2,64]}$ \\
\hline & Education on duration of antimicrobial therapy $(n=2 ; 4.6 \%)$ & Australia, ${ }^{[65]} \mathrm{USA}^{[56]}$ \\
\hline & Education on de-escalation linked to patient response $(n=2 ; 4.6 \%)$ & Australia, ${ }^{[65]} \mathrm{USA}^{[56]}$ \\
\hline & Training on considerations for IV-to-PO conversion $(n=2 ; 4.6 \%)$ & Australia, ${ }^{[65]} \mathrm{USA}^{[56]}$ \\
\hline & Information on antimicrobial spectra for various classes of antibiotics $(n=1 ; 2.3 \%)$ & $\mathrm{USA}^{[56]}$ \\
\hline & Information on antibiotic interactions and incompatibilities $(n=1 ; 2.3 \%)$ & $\mathrm{USA}^{[56]}$ \\
\hline & Education on common adverse reactions to antibiotics $(n=1 ; 2.3 \%)$ & $\mathrm{USA}^{[56]}$ \\
\hline & Training on assessment of a patient for a potential allergy to penicillin $(n=1 ; 2.3 \%)$ & $\mathrm{USA}^{[56]}$ \\
\hline & Training on therapeutic drug monitoring $(n=1 ; 2.3 \%)$ & $\mathrm{USA}^{[56]}$ \\
\hline & Education on antibiotic pharmacokinetics and pharmacodynamics $(n=1 ; 2.3 \%)$ & $\mathrm{USA}^{[57]}$ \\
\hline Collaboration & Assertiveness training to engage in discussions with the healthcare team $(n=1 ; 2.3 \%)$ & $\mathrm{USA}^{[56]}$ \\
\hline in AMS & Training on how to educate patients, family and carers about antimicrobials $(n=1 ; 2.3 \%)$ & Australia $^{[65]}$ \\
\hline
\end{tabular}

be given to the inclusion of nursing in interprofessional undergraduate AMS education (Table 2). The provision of appropriate AMS content into teaching curricula in the UK has required extensive consideration of various models of teaching/learning by multiprofessional bodies, including the RCN. ${ }^{[78]}$ Comparison of undergraduate healthcare students revealed a disparity between medical and nursing student exposure to AMS competency content: IPC (medicine 99\%; nursing 86\%); AMR and antimicrobials (medicine 99\%; nursing 56\%); prescribing antimicrobials (medicine 96\%; nursing 29\%); AMS (medicine 91\%; nursing 42\%); and monitoring and learning (medicine 63\%; nursing 16\%). ${ }^{[79]}$ Although most nursing faculties (63\%) integrated AMS in their curriculum, $<13 \%$ included all the recommended steps of stewardship. ${ }^{[80]}$ This led to the development of six core AMS domain competencies for nurse education: IPC; antimicrobials and AMR; diagnosis of infection and the use of antimicrobials; antimicrobial prescribing practice; personcentred care; and interprofessional collaborative practice, ${ }^{[1-83]}$ validated by an international consensus panel of nursing AMS experts from eight countries. ${ }^{[84]}$ These competencies provide the first AMS framework addressing the needs of this discipline for undergraduate nursing education in the UK. ${ }^{[83]}$

\section{AMS nurse education in the clinical environment}

Although increasing emphasis is placed on nurse education in AMS, this does not appear to have been translated to hospital settings. It is of concern that in general, nursing leaders and prescribers do not support nurses' involvement in AMS. ${ }^{[85]}$ Nurses collate clinical and microbiological information about the patients in their care and follow the trends of antimicrobial usage, ideally positioning them to influence decision-making regarding antibiotic use and supporting
AMS. ${ }^{[86]}$ Questioning the need for antimicrobial treatment therefore falls within nurse patient advocacy, ${ }^{[9,10,16,17,22,73,87-90]}$ but may be difficult within the hierarchical construct of healthcare dynamics. ${ }^{[4,10,15,20,91-94]}$ 'Nurses ability to discuss or even challenge antimicrobial management choices is heavily connected to the construct of power and knowledge, particularly within the acute care context. Nurses may not feel they are in a position to participate in ASPs [antimicrobial stewardship programmes] due to lack of knowledge, closely linked to positions of power. ${ }^{\text {'[16] }}$

The reviewed guidelines recommend that AMS training should be included in induction training for all newly appointed nursing staff (Table 2). A description of stewardship practice in 660 hospitals in 67 countries, across six continents, revealed that although $58 \%$ of hospitals surveyed had AMS programmes, bedside nurses received minimal introduction to these programmes, with only $16 \%$ of new nurses provided with AMS-related information on induction to a hospital. ${ }^{[95]}$ These findings were reflected in a 2016 UK survey ${ }^{[96]}$ of the implementation of AMS interventions recommended by national AMS toolkits, TARGET and Start Smart - Then Focus, where nurses were found to receive less AMS information (27\%) than pharmacists (69\%) and doctors (63\%) on induction in National Health Service (NHS) hospital trusts. A later study conducted in the USA by Abbas et al. ${ }^{[77]}$ found that only $19.5 \%$ of nurses reported having received formal training for AMS.

Recommendations have been made for the AMS team to develop a programme of ongoing education for bedside nurses (Table 2). The hospital AMS team has a vital role in providing knowledge to nursing staff to support nursing participation within AMS strategies. ${ }^{[97]}$ AMS ward rounds are the optimal time to transfer AMS skills to nurses and other members of the healthcare team, ${ }^{[16,94]}$ with these rounds noted to 
occur most commonly in intensive care units (74\%). ${ }^{[95]}$ Audit feedback from the AMS team is described by the Joint Commission as: 'regularly reporting information on the antimicrobial stewardship programme, which may include antibiotic use and resistance, to physicians and other practitioners, nurses, and relevant staff. ${ }^{\text {[64] }}$ This view supports the first of five strategic AMS goals developed in 1997 by the Society of Healthcare Epidemiology of America/Infectious Diseases Society of America (SHEA/ IDSA), ${ }^{[29]}$ in which recommendations were made to 'develop a system to recognize trends in antibiotic resistance and to report them promptly to hospital and physician leaders; medicine, nursing and infection control and pharmacy staff; and others who need to know'

\section{Developing safe nurse practice}

Although most of the guidelines recommended AMS education for clinical nurse practice (Table 2), they did not make recommendations to address identified medication administration problems. ${ }^{[35,47,57,65]}$ Specialised nursing expertise is essential for the safe administration of complex IV infusions, such as extended/prolonged infusions ${ }^{[57]}$ to avoid drug incompatibilities, ${ }^{[35]}$ and to support pharmacokinetic/ pharmacodynamic (PK/PD)-informed dosing strategies for dose optimisation. ${ }^{[4]}$ The safe disposal of antibiotic waste raised in the guidelines ${ }^{[65]}$ is corroborated by emerging evidence that antimicrobialresistant bacteria are found in areas where nurses drain antibiotics from discarded IV fluid bags/sets into hospital sinks. ${ }^{[98,99]}$

AMS best practice is founded on the principles of the right drug, the right dose, de-escalation when possible and the right duration, ${ }^{[33]}$ and there is an obligation for research to identify aspects of clinical nursing practice that fail to support these principles. ${ }^{[13,74]}$ AMR is a problem that should be viewed by all healthcare professionals in all healthcare settings as relevant to their particular disciplines. ${ }^{[68]}$ Continued research to identify knowledge needs of the bedside nurse is therefore essential, but the focus may not be entirely where it is needed, e.g. a long overdue examination of the effects of incorrect timing and/or missed doses of antimicrobial medicines. ${ }^{[23]}$ Where nursing research may not have the capacity to examine these issues, a multidisciplinary collaborative approach should be considered. ${ }^{[13]}$

\section{Study limitations}

The reviewers decided to include only recommendations indicated specifically for nurses: guidelines that included this role within general recommendations to healthcare professionals might have been excluded, unless it was stated that recommendations were aimed at all healthcare workers. Guidelines published in languages other than English would have been excluded. Search terms that were entered as plurals, may also be a potential limitation.

\section{Conclusions}

General lack of recognition of the important AMS roles of the bedside nurse creates a barrier to full nursing participation in AMS processes and their inclusion in the development and implementation of AMS strategies. Nursing representation in AMS is a pressing need, but not all nurses currently possess all the competencies required to fulfil this role. There is an evident need for continued formal recommendations for nurse clinical competencies. The under-acknowledged importance of nurses as partners within key AMS guidelines may be due to the focus on prescription of antimicrobial medicines (medicine/pharmacy), rather than appropriate management of administration once prescribed (medicine/nursing). If the nurse is inadequately prepared by nursing training, the implementation of clinical AMS programmes may not be effective. Recommendations for
AMR/AMS education to be included in undergraduate and postgraduate curricula should therefore be heeded. Until nursing programmes can provide appropriate training in AMR and AMS, hospitals and AMS teams must ensure that nurses are given every opportunity to gain knowledge and skills through induction training programmes, in-service training, and CPD.

\section{Declaration. None.}

\section{Acknowledgements. None.}

Author contributions. JR, SE and PB conceptualised the manuscript. JR analysed the data and wrote the manuscript. SE and PB analysed the data and revised the manuscript. All authors approved the final version of the manuscript for publication.

Funding. None.

Conflicts of interest. None.

1. World Health Organization. Global action plan on antimicrobial resistance. 2015. http://www who.int (accessed 5 November 2017).

2. Centers for Disease Control and Prevention. Core elements of hospital antibiotic stewardship programs. 2014. https://www.cdc.gov/antibiotic-use/healthcare/implementation/core-elements. html (accessed 10 June 2018).

3. Ohl C, Luther V. Health care provider education as a tool to enhance antibiotic stewardship practices. Infect Dis Clin N Am 2014;28(2):177-193. https://doi.org/10.1016/j.idc.2014.02.001

4. Monsees E, Popejoy L, Jackson M, Lee B, Goldman J. Integrating staff nurses in antibiotic stewardship: Opportunities and barriers. Am J Infect Control 2018;46(7):737-742. https://doi. org/10.1016/j.ajic.2018.03.028

5. Satterfield J, Miesner A, Percival K. The role of education in antimicrobial stewardship. J Hosp Infect 2020;105(2):130-141. https://doi.org/10.1016/j.mcna.2018.05.011

6. Wilson A. Antimicrobial resistance: What can nurses do? Br J Nurs 2019;28(1):16-17. https://doi. org/10.12968/bjon.2019.28.1.16

7. Scottish Antimicrobial Prescribing Group. Exploring the role of nurses and midwives in antimicrobial stewardship. NHS Education for Scotland. 2014. https://www.nes.scot.nhs.uk/ media/3065666/exploring_role_of_nurses_and_midwives_in_antimicrobial_stewardship_report. pdf (accessed 15 September 2019).

8. Mostaghim M, Snelling T, McMullan B, et al. Nurses are underutilised in antimicrobial stewardship. Results of a multisite survey in paediatric and adult hospitals. Infect Dis Health 2017;22(2):57-64. https://doi.org/10.1016/j.idh.2017.04.003

9. Rout J, Brysiewicz P. Exploring the role of the ICU nurse in the antimicrobial stewardship team at a private hospital in KwaZulu-Natal, South Africa. South Afr J Crit Care 2017;33(2):46-50. https:// doi.org/10.7196/SAJCC.2017.v33i2.331

10. Carter E, Greendyke W, Furuya E, et al. Exploring the nurses' role in antibiotic stewardship: A multisite qualitative study of nurses and infection preventionists. Am J Infect Control 2018;46(5):492-497. https://doi.org/10.1016/j.ajic.2017.12.016

11. Greendyke W, Carter E, Salsgiver E, et al. Exploring the role of the bedside nurse in antimicrobial stewardship: Survey results from five acute-care hospitals. Infect Control Hosp Epidemiol 2018;39(3):360-362. https://doi.org/10.1017/ice.2017.255

12. Merrill K, Forsyth Hanson S, Sumner S, Vento T, Veillette J, Webb B. Antimicrobial stewardship: Staff nurse knowledge and attitudes. Am J Infect Control 2019;47(10):1219-1224. https://doi, org/10.1016/j.ajic.2019.03.022

13. Rout J, Essack S, Brysiewicz P. Are nursing infusion practices delivering full-dose antimicrobial treatment? J Antimicrob Chemother 2019;74(12):3418-3422. https://doi.org/10.1093/jac/dkz365

14. Wilcock M, Powell N, Underwood F. Antimicrobial stewardship and the hospital nurse and midwife: How do they perceive their role? Eur J Hosp Pharm 2019;26(2):89-92. https://doi. org/10.1136/ejhpharm-2017-001312

15. Rout J, Brysiewicz P. Perceived barriers to the development of the antimicrobial stewardship role of the nurse in intensive care: Views of healthcare professionals. South Afr J Crit Care 2020;36(1):51-56. https://doi.org/10.7196/sajcc.2020.v36i1.410

16. Edwards R, Drumright L, Kieran M, Holmes A. Covering more territory to fight resistance: Considering nurses' role in antimicrobial stewardship. J Infect Prev 2011;12(1):6-10. https://doi. org/10.1177/1757177410389627

17. Gillespie E, Rodrigues A, Wright L, Williams N, Stuart R. Improving antibiotic stewardship by involving nurses. Am J Infect Control 2012;41(4):365-367. https://doi.org/10.1016/j. ajic.2012.04.336

18. Olans R, Nicholas P, Hanley D, DeMaria A. Defining a role for nursing education for staff nurse participation in antimicrobial stewardship. J Contin Educ in Nurs 2015;46(7):318-321. https://doi. org/10.3928/00220124-20150619-03

19. Olans RN, Olans RD, DeMaria A. The critical role of the staff nurse in antimicrobial stewardship - unrecognised, but already there. Clin Infect Dis 2016;62(1):84-89. https://doi.org/10.1093/cid/ civ697

20. Broom A, Broom J, Kirby E, Scambler G. Nurses as antibiotic brokers: Institutionalized praxis in the hospital. Qual Health Res 2016;27(13):1924-1935. https://doi.org/10.1177/1049732316679953

21. Cavadid C, Sakamoto S, Terashita D, Schwartz B. Bedside registered nurse roles in antimicrobial stewardship: A survey of acute-care hospitals in Los Angeles County. Infect Control Hosp Epidemiol 2017;38(10):1263-1265. https://doi.org/10.1017/ice.2017.166

22. Jeffs L, Law M, Zahradnik M, et al. Engaging nurses in optimizing antimicrobial use in ICUs. A qualitative study. J Nurs Care Qual 2018;33(2):173-179. https://doi.org/10.1097/ NCQ.0000000000000281

23. Royal College of Nursing. Antimicrobial Resistance. RCN Position on the Nursing Contribution. London: RCN, 2014

24. Joanna Briggs Institute. Methodology for JBI Scoping Reviews. Joanna Briggs Institute Reviewer's Manual. Adelaide: JBI, 2015 
25. Arksey H, O’Malley L. Scoping studies: Towards a methodological framework. Int J Soc Res Meth 2005;8(1):19-32. https://doi.org/10.1080/1364557032000119616

26. Levac D, Colquhoun H, O'Brien K. Scoping studies: Advancing the methodology. Implement Sci 2010;5(1):1-9. https://doi.org/10.1186/1748-5908-5-69

27. Tricco A, Lillie E, Zarin W, et al. PRISMA extension for scoping reviews (PRISMA-ScR): Checklist and explanation. Ann Intern 2018;169(7):467-473. https://doi.org/10.7326/M18-0850

28. Rout J, Essack S, Brysiewicz P. Guidelines for the hospital role of the clinical nurse in antimicrobial stewardship: A scoping review. South Afr J Crit Care 2021:37(2):70-76. https://doi. org/10.7196\%2FSAJCC.2021.v37i2.481

29. Shlaes D, Gerding D, John J, et al. Society for Healthcare Epidemiology of America and Infectious Diseases Society of America Joint Committee on the Prevention of Antimicrobial Resistance Guidelines for the prevention of antimicrobial resistance in hospitals. Clin Infect Dis 1997;25(3):584 599. https://doi.org/10.1086/513766

30. Peters M, Godfrey C, Khalil H, McInerney P, Parker D, Soares C. Guidance for conducting systematic scoping reviews. Int J Evid Based Healthc 2015;13(3):141-146. https://doi.org/10.1097 XEB.0000000000000050

31. Pham M, Rajić A, Greig J, Sargeant J, Papadopoulos A, McEwen S. A scoping review of scoping reviews: Advancing the approach and enhancing the consistency. Res Synth Methods 2014;5(4):371-385. https:// doi.org/10.1002/jrsm.1123

32. Nathwani D. Antimicrobial prescribing policy and practice in Scotland: Recommendations for good antimicrobial practice in acute hospitals. J Antimicrob Chemother 2006;57(6):1189-1196. https://doi org/10.1093/jac/dkl137

33. Dellit T, Owens R, McGowan J, et al. Guidelines for developing an institutional program to enhance antimicrobial stewardship. Clin Infect Dis 2007;44(2):159-177. https://doi.org/10.1086/510393

34. Strategy for the Control of Antimicrobial Resistance in Ireland. SARI Annual Report. 2007. https://www.hpsc.ie/a-z/microbiologyantimicrobialresistance/ strategyforthecontrolofantimicrobialresistanceinirelandsari/sariannualreports/File,3202,en.pdf (accessed 30 July 2018).

35. Drew R, White R, MacDougall C, Hermsen E, Owens R. Insights from the Society of Infectious Diseases Pharmacists on antimicrobial stewardship guidelines from the Infectious Diseases Society of America and the Society for Healthcare Epidemiology of America. Pharmacotherapy 2009;29(5):593607. https://doi.org/10.1592/phco.29.5.593

36. Strategy for the Control of Antimicrobial Resistance in Ireland. Guidelines for antimicrobial stewardship in hospitals in Ireland. 2009. https://www.hpsc.ie/a-z/microbiologyantimicrobialresistance/ infectioncontrolandhai/guidelines/File,4116,en.pdf (accessed 30 July2018).

37. Duguid M, Cruikshank M. Antimicrobial stewardship in Australian hospitals. Australian Commission on Safety and Quality in Healthcare. 2011. https://www.safetyandquality.gov.au/sites/default/files/ migrated/Antimicrobial-stewardship-in-Australian-Hospitals-2011.pdf (accessed 30 July 2018).

38. Spellberg B, Blaser M, Guidos R, et al. Combating antimicrobial resistance: Policy recommendations to save lives. Clin Infect Dis 2011;52(Suppl 5):S397-S428. https://doi.org/10.1093/cid/cir153

39. Society for Healthcare Epidemiology of America, Infectious Diseases Society of America, Pediatric Infectious Diseases Society. Policy statement on antimicrobial stewardship by the Society for Healthcare Epidemiology of America (SHEA), the Infectious Diseases Society of America (IDSA), and the Epidemiology of America (SHEA), the Infectious Diseases Society of America (IDSA), and the
Pediatric Infectious Diseases Society (PIDS). Infect Control Hosp Epidemiol 2012;33(4):322-327. Pediatric Infectious Diseases
https://doi.org/10.1086/665010

40. Teng C, Lee W, Yeo C, et al. Guidelines for antimicrobial stewardship training and practice. Ann Acad Med Singapore 2012;41(1):29-34.

41. Public Health England. Antimicrobial prescribing and stewardship competencies. 2013. https://www. gov.uk/government/publications/antimicrobial-prescribing-andstewardship competencies (accessed 30 July 2018).

42. National Department of Health. Antimicrobial Resistance National Strategy Framework 2014 - 2024 Pretoria: NDoH, 2014. https://www.health-e.org.za/../2015/../Antimicrobial-Resistance-NationaStrategy-Fram... (accessed 30 July 2018).

43. Ministry of Health. Protocol on Antimicrobial Stewardship Program. Malaysia: MoH, 2014. http://www. moh.gov.my/.../554756755a584a69615852686269394859584a706379425159 (accessed 30 July 2018).

44. National Department of Health. Implementation Plan for the Antimicrobial Resistance Strategy Framework in South Africa: 2014 - 2019. Pretoria: NDoH, 2015. https://www.health.gov.za/. antimicrobial-resistance?...implementation-plan-for-the-antimic... (accessed 30 July 2018).

45. Department of Health. Antimicrobial Stewardship Policy. Western Australia: DoH, 2015. http://www. safetyandquality.health.wa.gov.au/home/index.cfm (accessed 30 July 2018).

46. Communicable and Infectious Disease Steering Committee (CIDSC). Task Group on Antimicrobia Use Stewardship - executive summary. Pan-Canadian Health Public Network. 2016. http://www.phnrsp.ca/pubs/anstew-gestan/pdf/pub-eng.pdf (accessed 30 July 2018).

47. Barlam T, Cosgrove S, Abbo L, et al. Implementing an antibiotic stewardship program: Guidelines by the Infectious Diseases Society of America and the Society for Healthcare Epidemiology of America. Clin Infect Dis 2016;62(10):e51-e77. https://doi.org/10.1093/cid/ciw118

48. National Department of Health. Antimicrobial Resistance - Background Document. Pretoria: $\mathrm{NDoH}$ 2016. https://www.fidssa.co.za/Content/Documents/AMR_Background_document_FINAL_March15. pdf (accessed 30 July 2018).

49. National Department of Health. A Practical Guide to Antimicrobial Stewardship in South Africa. Pretoria NDoH, 2016. https://www.health.gov.za/index.php/antimicrobial-resistance (accessed 30 July 2018).

50. De With K, Allerberger F, Amann S, et al. Strategies to enhance rational use of antibiotics in hospital A guideline by the German Society for Infectious Diseases. Infection 2016;44(3):395-439. https://doi org/10.1007/s15010-016-0885-z

51. HealthCare CAN and National Collaborating Centre for Infectious Diseases. Putting the pieces together: A national action plan on antimicrobial stewardship. 2016. - https://nccid.ca/wp-content/ uploads/sites/2/2017/01/Putting-the-Pieces-Together.pdf (accessed 30 July 2018).

52. Healthcare Infection Control Practices Advisory Committee. Antibiotic stewardship statement for antibiotic guidelines - recommendations from HICPAC. 2016. https://www.cdc.gov/hicpac/pd/ antibiotic-stewardship-statement.pdf (accessed 30 July 2018).

53. Levy Hara G, Kanj S, Pagani L, et al. Ten key points for the appropriate use of antibiotics in hospitalised patients: A consensus from the Antimicrobial Stewardship and Resistance Working Groups of the International Society of Chemotherapy. Int J Antimicrob Agents 2016;48(3):239-246. https://doi org/10.1016/j.ijantimicag.2016.06.015

54. Morgan D, Croft L, Deloney V, et al. Choosing wisely in healthcare epidemiology and antimicrobial stewardship. Infect Control Hosp Epidemiol 2016;37(7):755-760. https://doi.org/10.1017/ice.2016.61

55. National Institute for Health and Care Excellence. Antimicrobial stewardship. 2016. https://www. nice.org.uk/guidance/qs121/resources/antimicrobial-stewardship-pdf-75545353537477 (accessed 30 July 2018).

6. American Association of Nurses. White paper: Redefining the antibiotic stewardship team Recommendations from the American Nurses Association/Centers for Disease Control an Prevention Workgroup on the Role of Registered Nurses in Hospital Antibiotic Stewardship Practices. Maryland: AAN, 2017. https://www.cdc.gov/antibiotic-use/healthcare/pdfs/ANA-CDCwhitepaper.pdf (accessed 30 July 2018).
57. American Society of Health-System Pharmacists. A hospital pharmacist's guide to antimicrobial tewardship. 2017. https://www.scribd.com/document/312641269/Stewardship-White-Paper (accessed 30 July 2018).

58. Canadian Nurses Association. Antimicrobial resistance in Canada. Brief for the Standing Committe on Health. 2017. https://www.cna-aiic.ca/ /media/cna/page-content/pdf-en/antimicrobialresistance-in-canada-brief-for-the-standing-committee-on-health.pdf?la=en (accessed 30 July 2018)

59. Department of Health. Australia’s first national antimicrobial resistance strategy 2015 - 2019 progres report. 2017. https://www.amr.gov.au/australias-response/national-amr-strategy (accessed 30 July 2018).

60. European Commission. EU Guidelines for the Prudent Use of Antimicrobials in Human Health Brussels: EU, 2017. https://ec.europa.eu/health/amr/sites/amr/files/amr_guidelines_prudent_use en.pdf (accessed 30 July 2018).

61. European Federation of Nurses Associations. Nurses are frontline combating antimicrobial resistance. 2017. http://www.efnweb.be/wp-content/uploads/EFN-AMR-Report-Nurses-are-frontlinecombating-AMR-07-11-2017.pdf (accessed 30 July 2018).

62. International Council of Nurses. Position statement. Antimicrobial resistance. 2017. https://www.icn. $\mathrm{ch} /$ sites/default/files/inline-files/PS_A_Antimicrobial_resistance.pdf (accessed 30 July 2018).

63. National Department of Health. Guidelines on Implementation of Antimicrobial Stewardship in outh Africa: One Health Approach and Governance. Pretoria: NDoH, 2017. https://www.health. gov.za/.../antimicrobial-resistance?...antimicrobial-stewardship-guidelines... (accessed 30 July 2018).

64. The Joint Commission. New antimicrobial stewardship standard. 2017. https://www.jointcommission org/assets/1/6/New_Antimicrobial_Stewardship_Standard.pdf (accessed 30 July 2018).

65. Australian Commission on Safety and Quality in Health Care. Antimicrobial stewardship in Australian health care. 2018. https://www.safetyandquality.gov.au/our-work/healthcare-associatedinfection/antimicrobial-stewardship/book/ (accessed 30 July 2018).

66. Hawkey P, Warren R, Livermore D, et al. Treatment of infections caused by multidrug-resistant Gram negative bacteria: Report of the British Society for Antimicrobial Chemotherapy/Healthcare Infection Society/British Infection Association Joint Working Party. J Antimicrob Chemother 2018;73(Supp 3):iii2-iii78. https://doi.org/10.1093/jac/dky027

67. Manning M, Septimus E, Dodds AW, et al. Antimicrobial stewardship and infection prevention leveraging the synergy: A position paper update. Am J Infect Control 2018;46(4):364-368. https://doi. org/10.1016/.jajic.2018.01.001

68. World Health Organization. Competency Framework for Health Workers' Education and Training on Antimicrobial Resistance. Geneva: WHO, 2018. https://www.who.int/hrh/resources/WHO-HIS HWF-AMR-2018.1/en/ (accessed 10 September 2019).

69. Centers for Disease Control and Prevention. The core elements of hospital antibiotic stewardship programs. 2019. https://www.cdc.gov/antibiotic-use/healthcare/pdfs/hospital-core-elements-H.pdf (accessed 30 January 2020)

70. Department of Health. Guidelines for the Prevention and Containment of Antimicrobial Resistance in South African Hospitals. Pretoria: NDoH, 2019. https://www.fidssa.co.za/Content/Documents/ 2019SAGuidelineAMRHospitals.pdf (accessed 30 January 2020)

71. Hawking M, Ashiru-Oredope D, Northeast S, McNulty C. Antimicrobial stewardship: How can nurse contribute? Nurse Prescribing 2014;12(11):536-553

72. World Health Organization. Mapping Educational Opportunities and Resources for Healthcare Workers to Learn About Antimicrobial Resistance and Stewardship. Human Resources for Health Observer Series No. 21. Geneva: WHO, 2017. https://apps.who.int/iris/bitstream/hand le/10665/259362/9789241512787-eng.pdf;sequence=1 (accessed 30 September 2019).

73. Manning M, Pfeiffer J, Larson E. Combating antibiotic resistance: The role of nursing in antibiotic stewardship. Am J Infect Control 2016;44(12):1454-1457. https://doi.org/10.1016/.j.ajc.2016.06.023

74. Schellack N, Pretorius R, Messina A. 'Esprit de corps': Towards collaborative integration of pharmacists and nurses into antimicrobial stewardship programmes in South Africa. S Afr Med J 2016;106(10):973-974. https://doi.org/10.7196/SAMJ.2016.v106i10.11468

75. Pereira N, Castro-Sánchez E, Nathwani D. How can multi-professional education support better stewardship? Infect Dis Rep 2017;9(10):1-7. https://doi.org/10.4081/idr.2017.6917

76. Ladenheim D. Role of nurses in supporting antimicrobial stewardship. Nurs Stand 2018;33(6):55-58 https://doi.org/10.7748/ns.2018.el1245

77. Abbas S, Lee K, Pakyz A, et al. Knowledge, attitudes, and practices of bedside nursing staff regarding antibiotic stewardship: A cross-sectional study. Am J Infect Control 2019:47(3):230-233. https://doi. org/10.1016/j.ajic.2018.09.008

78. Ashiru-Oredope D, Cookson B, Fry C. Developing the first national antimicrobial prescribing and stewardship competences. J Antimicrob Chemother 2014;69(11):2886-2888. https://doi.org/10.1093 jac/dku350

79. Health Education England. Embedding national antimicrobial prescribing and stewardship competences into curricula. A survey of health education institutions. Full report. 2016. http://www: hee.nhs.uk (accessed 25 January 2019).

80. Castro-Sánchez E, Drumright L, Gharbi M, Farrell S, Holmes A. Mapping antimicrobial stewardship in undergraduate medical, dental, pharmacy, nursing and veterinary education in the United Kingdom. PLoS ONE 2016;11(2):e0150056. https://doi.org/10.1371/journal.pone.0150056

81. Courtenay M, Castro-Sánchez E, Deslandes R, et al. Defining antimicrobial stewardship competencies for undergraduate health professional education in the United Kingdom: A study protocol. I Interprof Care 2018;32(5):638-640. https://doi.org/10.1080/13561820.2018.1463200

82. Courtenay M, Lim R, Castro-Sánchez E, et al. Development of consensus-based national antimicrobia stewardship competencies for UK undergraduate healthcare professional education. J Hosp Infect 2018;100(3):245-256. https://doi.org/10.1016/j.jhin.2018.06.022

83. Courtenay M, McEwan J. Applying an antimicrobial stewardship competency framework in nurse education and practice. Nurs Stand 2020;35(3):41-46. https://doi.org/10.7748/ns.2020.e11488

84. Courtenay M, Castro-Sánchez E, Gallagher R, et al. Development of consensus-based international antimicrobial stewardship competencies for undergraduate nurse education. J Hosp Infect 2019;103(3):244-250. https://doi.org/10.1016/j.jhin.2019.08.001

85. Monsees E, Goldman J, Vogelsmeier A, Popejoy L. Nurses as antimicrobial stewards: Recognition, confidence, and organisational factors across nine hospitals. Am J Infect Control 2020;48(3):239-245. https://doi.org/10.1016/j.ajic.2019.12.002

86. Charani E, Castro-Sánchez E, Holmes A. The role of behavior change in antimicrobial stewardship. Infect Dis Clin North Am 2014;28(2):169-175. https://doi.org/10.1016/j.idc.2014.01.004

87. Jutel A, Menkes D. Nurses' reported influence on the prescription and use of medication. Int Nurs Rev 2010;57(1):92-97. https://doi.org/10.1111/j.1466-7657.2009.00749.x

88. Fry C. Antimicrobial resistance, responsible prescribing - a call to action for nurses. J Infect Prev 2012;13(6):182.

89. Manning M, Giannuzzi D. Keeping patients safe: Antibiotic resistance and the role of nurse executives in antibiotic stewardship. J Nurs Adm 2015;45(2):67-69. https://doi.org/10.1097/ nna.0000000000000159

90. Sumner S, Forsyth S, Collette-Merrill K, et al. Antibiotic stewardship: The role of clinical nurses and nurse educators. Nurse Educ Today 2018;60:157-160. https://doi.org/10.1016/. nedt.2017.10.011 
91. Broom A, Gibson A, Broom J, Kirby E, Yarwood T, Post J. Optimizing antibiotic usage in hospitals: A qualitative study of the perspectives of hospital managers. J Hosp Infect 2016;94(3):230-235. https:// doi.org/10.1016/j.jhin.2016.08.021

92. Charani E, Holmes A. Antibiotic stewardship - twenty years in the making. Antibiotics 2019;8(1):pii. E7. https://doi.org/10.3390\%2Fantibiotics8010007

93. Kirby E, Broom A, Overton K, Kenny K, Post J, Broom J. Reconsidering the nursing role in antimicrobial stewardship: A multisite qualitative interview study. BMJ Open 2020;10(10):e042321. https://doi.org/ $0.1136 /$ mispen-2020-042321

94. Wong L, Ibrahim M, Guo H, et al. Empowerment of nurses in antibiotic stewardship: A social ecological qualitative analysis. J Hosp Infect 2020;106(3):473-482. https://doi.org/10.1016/j.jhin.2020.09.002

95. Howard P, Pulcini C, Levy Hara G, et al. An international cross-sectional survey of antimicrobial stewardship programmes in hospitals. J Antimicrob Chemother 2015;70(4):1245-1255. https://doi. org/10.1093/jac/dku497

96. Ashiru-Oredope D, Budd E, Bhattacharya A, et al. Implementation of antimicrobial stewardship interventions recommended by national toolkits in primary and secondary healthcare sectors in
England: TARGET and Start Smart Then Focus. J Antimicrob Chemother 2016;71(5):1408-1414. https://doi.org/10.1093/jac/dkv492
97. Pollack L, Srivasan A. Core elements of hospital antibiotic stewardship programs from the Centers for Disease Control and Prevention. Clin Infect Dis 2014;59(3):S97-S100. https://doi. org/10.1093/cid/ciu542

98. Kotay S, Chai W, Guilford W, Barry K, Mathers A. Spread from the sink to the patient: In situ study using green fluorescent protein (GFP) - expressing Escherichia coli to model bacterial dispersion from hand-washing sink-trap reservoirs. Appl Environ Microbiol 2017;83(8):1-12. https://doi.org/10.1128/AEM.03327-16

99. Grabowski M, Lobo J, Gunnell B, Enfield K, Carpenter R, Barnes L. Characterizations of handwashing sink activities in a single hospital medical intensive care unit. J Hosp Infect 2018;100(3):e115-e122. https://doi.org/10.1016/j.jhin.2018.04.025

Accepted 12 April 2021 